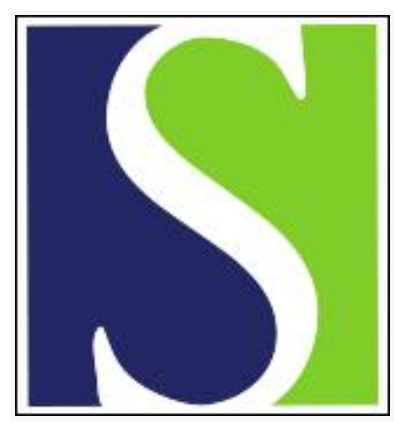

Scand J Work Environ Health 2006;32(1):1-4

https://doi.org/10.5271/sjweh.969

Issue date: 31 Feb 2006

\title{
Expanding research on the economics of occupational health
}

by Leigh JP

Affiliation: Center for Health Services Research in Primary Care and Department of Public Health Sciences, University of California, Medical School, TB 168, Davis, CA 95616-8638, USA. pleigh@ucdavis.edu

The following articles refer to this text: 2007;33(3):161-164;

2007;33(4):241-243; 2010;36(4):273-288; 2012;38(5):393-408;

2018;44(2):171-182

Key terms: economics; editorial; occupational health

This article in PubMed: www.ncbi.nlm.nih.gov/pubmed/16539165

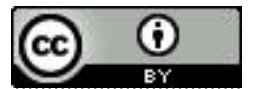




\section{Editorial}

Scand J Work Environ Health 2006;32(1):1-4

\section{Expanding research on the economics of occupational health}

The paper by Schmier et al (1), published in this issue of the Scandinavian Journal of Work, Environment \& Health, is a splendid example of the expanding research on the economics of occupational health. A literature search in PubMed using simply "occupational health" and "economics" yielded 3220 studies since 1952. PubMed listed 41 studies for the 1950s and 1960s, 289 for the 1970s, 569 for the 1980s, 1228 for the 1990s, and 1093 for the first half of the 2000s. But PubMed only details medical literature. One theme of this editorial is that medical researchers should also consider the economics literature (isiknowledge.com). Given the enormity of both sets of literature, this editorial can only touch on some topics, for example, costs to employers as a result of smoking and obesity, health promotion, cost-benefit and effectiveness, total costs, workers' compensation, influence of the United States (US) Occupational Safety and Health Administration (OSHA), the compensating wage hypothesis, and other topics.

Beginning with Kristein's paper in 1983 (2), many studies have addressed whether smoking cessation programs can affect business profits and workers' wages and, if so, by how much $(3,4)$. Schmier et al (1) and Finkelstein et al (5) are the first studies, I believe, to estimate employer costs due to obesity. These papers will likely be as influential as Kristein's paper on smoking. Nevertheless, future research into employers' costs of obesity will have to address several shortcomings. People do not become obese by accident. There are "predictors" of obesity, and without proper account of these predictors the "true" effect of obesity on costs cannot be determined. The medical literature typically "controls for" age, gender, region of residence, and access to medical care as predictors of obesity. Economists tend to "control for" much more (eg, years of schooling, presence of married spouse, separated, divorced, never married, widowed, several categories of race, years of work experience, income from spouse, number of children in family). More importantly, economists attempt to control for self-selection with an econometric technique of instrumental variables (6). There are likely to be predictors of obesity that we do not have in our data sets, such as tastes for risks, ability to delay gratification, and time discount preferences. If these unmeasured predictors lead to both obesity and, say, absenteeism, then our statistical analysis will overestimate the effects of obesity on absenteeism. The econometric techniqueinstrumental variables-removes the bias of unobserved predictors. When this technique has been applied, smaller effects of smoking on absenteeism (7) and wages (3) are observed.

It is important to generate the most accurate estimate possible. Not only can business decisions and profits be affected, but individual workers too. Smoking and obesity are more prevalent among the poor than the rich (8). Employers may discriminate by not hiring smokers or obese persons and thereby discriminate against the poor (9).

In the early 1980s in the United States, several corporations experimented with health promotion programs for their employees. Gyms, jogging tracks, and even swimming pools were constructed on site. Formal and informal inducements were offered for employees to participate. The hope was that these programs would raise morale, reduce absenteeism, improve productivity, and, especially, reduce rising medical insurance premiums, which, in the United States, are a fringe benefit tied to employment. These programs have had some success, especially among white-collar workers, but have yet to gain sufficient traction among blue-collar workers, especially those in unions. The feeling is that "management" will substitute these programs for investments in safety equipment and reductions in workplace toxins. 
Many studies have been conducted. Jeffery et al (10) considered smoking cessation and weight control programs. Howard (11) suggested that second-hand smoking is an occupational hazard. Shein \& Krammer (12) provide a review. Most of these studies are not randomized trials, however. Current research does not adequately adjust for self-selection either with enrollment into a program or with becoming a smoker or jogger before being employed.

Studies on the benefits, costs, and effectiveness of workplace interventions have enjoyed the greatest growth and will likely include most of the studies on the economics of occupational health in the future. Reviews of the literature are available (13-15). These studies can sometimes command immediate attention and have practical results since they can make a "business case" for or against intervention. Although the methodology of the typical study improves each year, problems persist pertaining to definitions of costs, distinguishing between average and marginal costs, a clear statement of the "base case," and measurement of productivity (13-15).

Another research area with growth has involved estimates of the total costs of occupational injuries and illnesses. These costs were estimated to be USD 171 in 1992, which placed them on par with the costs of cancer in the United States (16). Total costs have also been estimated in Lebanon (17) and New Zealand (18). Many of these studies are old and limited to only a handful of countries, diseases, and injuries. They are ripe topics for future research. A key ingredient, frequently missing in prior studies, is a sensitivity analysis, since so much depends on the assumptions of the models.

Workers' compensation is the oldest and most voluminous line of research in the field of the economics of occupational health (19). One question involves the extent to which the ratio of cash benefits to wages (replacement ratio) for workers encourage filing claims. Economists have devoted considerable effort to answering this question (20). Even though there is no consensus, many studies suggest that roughly a $10 \%$ increase in benefits is associated with a $1 \%$ to $4 \%$ increase in the numbers of claims and the duration of claims. But methodological problems afflict many studies. For example, no studies with which I am aware fully account for the endogenous nature (covariate confounding problems) associated with wages. Across white- and blue-collar jobs, low wages are associated with high job hazards (blue-collar jobs tend to be more hazardous than white-collar ones). Looking only at blue-collar jobs, the compensation wage hypothesis suggests that low wages are associated with low hazards. The ratio itself, therefore, is an indirect measure of job hazards, and any analysis that does not account for this confounding is biased.

A second workers' compensation question involves whether workers who would likely qualify for workers' compensation benefits actually receive them. One study finds $50 \%$ or more never do (21). A third workers' compensation question involves occupational disease. Most observers acknowledge that workers' compensation falls short of adequately compensating occupational disease within the United States and elsewhere $(22,23)$.

A promising area for future research would involve estimating the amount of fraud in workers' compensation. I am unaware of any scientific study of fraud in workers' compensation. The US General Accounting Office under the current Bush administration estimated unemployment insurance fraud to be $2.16 \%$ of all unemployment insurance spending (24). But any analysis of workers' compensation should also account for white-collar fraud by insurance companies. This amount is likely to be significant. These companies, after all, have the same profit motive as nonworkers' compensation HMOs (health maintenance organizations) and private health insurance companies that middle-class Americans so frequently deride.

The father of economics, Adam Smith, has had two lasting influences on occupational health issues. The first was his suggestion that capitalism would have a tendency to create repetitive jobs that would make workers "stupid and ignorant" and incapable of defending their country in war. Smith advocated for government intervention to "take some pains to prevent" this degradation of workers (25). In the 
United States, the OSHA Act of 1970 was just such a government intervention. Many economic studies suggest that OSHA's direct effects (via fines and penalties) on reducing injury rates have been minimal. Indirect effects (via compliance and costs imposed on small, nonunionized firms) may have been significant, however (26).

The second Adam Smith influence involved his compensating wage hypothesis, which holds that "the market" will punish employers providing dangerous jobs. If workers are well-informed about hazards and are mobile, employers with dangerous jobs can only attract employees by offering to "compensate" workers with a high wage. Some studies find evidence for the compensating wage hypothesis, whereas others do not (27-30). The critical studies that do not find evidence for the hypothesis point to the assumptions of the hypothesis. Critical studies suggest that workers may not know which jobs entail which hazards and that some workers, especially poor workers, may not have much choice in rejecting or quitting a job (ie, they may have limited mobility).

One way to improve the ability of "the market" to punish employers offering dangerous jobs is to publicize information on job hazards. In the United States, the government requires all packages of potato chips to contain information on fat content. Governments could require that all job application forms contain information on fatality rates (31).

There are additional topics that should be mentioned as growth areas. They include studies focusing on undercounting occupational injuries (32-33), health services research (34-36), job hazards as predictors of early retirement and disability pensions (37), and absenteeism $(38,39)$.

Medical professionals within the field of occupational health have always encouraged interdisciplinary research. It is not surprising, therefore, that the literature on the economics of occupational health has been expanding, and papers like that of Schmier et al (1) will be so widely cited. This expansion will likely "spill over" into other areas as a result of the increasing concern about costs across all medical fields. Given that many health economists currently practice within occupational health, this "spill-over" could enhance the influence of occupational health on other areas of medicine.

\section{References}

1. Schmier JK, Jones ML, Halpern MT. The cost of obesity in the workplace. Scand J Work Environ Health. 2006;32(1):511.

2. Kristein MM. How much can business expect to profit from smoking cessation. Prev Med. 1983;12(2):358-81.

3. Levine PB, Gustafson TA, Velenchik AD. More bad news for smokers? The effects of cigarette smoking on wages. Ind Labor Relat Rev. 1997;50(3):493-509.

4. Warner KE. Selling health promotion to corporate America—uses and abuses of the economic argument. Health Educ Q. 1987;14(1):39-55.

5. Finkelstein E, Fiebelkorn IC, Wang GJ. The costs of obesity among full-time employees. Am J Health Promot. 2005;20(1):45-51.

6. Leigh JP, Schembri M. Instrumental variables technique: cigarette price provided better estimate of effects of smoking on SF-12. J Clin Epidemiol. 2004;57(3):284-93.

7. Leigh JP. Smoking, self-selection and absenteeism. Q Rev Econ Finance. 1995;35(4):365-86.

8. Chou SY, Grossman M, Saffer H. An economic analysis of adult obesity: results from the Behavioral Risk Factor Surveillance System. J Health Econ. 2004;23(3):565-87.

9. Simon HA, Noonan AM. No smokers need apply-is refusing to hire smokers legal. Employee Relat Law J. 1995;20(3):347-67.

10. Jeffery RW, Forster JL, French SA, Kelder SH, Lando HA, McGovern PG, et al. The healthy worker project-a work-site intervention for weight control and smoking cessation. Am J Public Health. 1993;83(3):395-401.

11. Howard J. Smoking is an occupational hazard. Am J Ind Med. 2004;46(2):161-9.

12. Shein M, Kramer DM. Health promotion in the workplace: framing the concept; reviewing the evidence. Occup Environ Med. 2004;61(7):643-8.

13. Goldenhar LM, Schulte PA. Intervention research in occupational health and safety. J Occup Environ Med. 1994;36(7):763-75.

14. Lahiri S, Gold J, Levenstein C. Net-cost model for workplace interventions. J Safety Res. 2005;36(3):241-55.

15. Biddle E, Ray T, Owusu-Edusei K Jr, Camm T. Synthesis and recommendations of the economic evaluation of OHS interventions at the company level conference. J Safety Res. 2005;36(3):261-7.

16. Leigh JP, Markowitz SB, Fahs M, Shin C, Landrigan PJ. Occupational injury and illness in the US: estimates of costs, 
morbidity, and mortality. Arch Int Med. 1997;157(14):1557-68.

17. Fayad R, Nuwayhid I, Tamin H, Kassak K, Khogali M. Cost of work-related injuries in insured workplaces in Lebanon. Bull World Health Organ. 2003;81(7):509-16.

18. 't Mannetje A, Pearce N. Quantitative estimates of work-related death, disease and injury in New Zealand. Scand J Work Environ Health. 2005;31(4):266-76

19. Boden LI. Workers' compensation in the United States: high costs, low benefits. Ann Rev Public Health. 1995;16:189_ 218.

20. Loeser JD, Henderlite SE, Conrad DA. Incentive effects of workers compensation benefits-a literature synthesis. Med Care Res Rev. 1995;52(1):34-59.

21. Biddle J, Roberts K, Rosenman KD, Welch EM. What percentage of workers with work-related illnesses receive workers' compensation benefits? J Occup Environ Med. 1998;40(4):325-31.

22. Leigh JP, Robbins JA. Occupational disease and workers compensation: coverage, costs and consequences. Milbank Q. 2004;82(4):689-721.

23. Hoet P, Lison D. The practice of occupational and environmental health in Belgium. Int Arch Occup Environ Health. 1996;68(3):137-40.

24. US General Accounting Office. Unemployment insurance: increased focus on program integrity could reduce billions in overpayments (GAO-02-697). Washington (DC): US Government Printing Office; 2002.

25. Smith A. An inquiry into the nature and causes of the wealth of nations, vol 2, book 5. In: Campbell RH, Skinner AS, Todd WB, editors. London: Clarendon Press; 1976. p 302.

26. Weil D. If OSHA is so bad, why is compliance so good? Rand J Econ. 1996;27(3):618-40.

27. Viscusi WK, Aldy JE. The value of a statistical life: a critical review of market estimates throughout the world. J Risk Uncertainty. 2003;27(1):5-76.

28. Purse K. Work-related fatality risks and neoclassical compensating wage differentials. Cambridge J Econ. 2004;28(4):597-617.

29. Leigh JP. Compensating wages, value of a statistical life, and interindustrial differentials. J Environ Econ Manage. 1995;28(1):83-97.

30. Dorman P, Hagstrom P. Wage compensation for dangerous work revisited. Ind Labor Relat Rev. 1998;52(1):116-35.

31. Leigh JP. A report card for occupational injuries and illnesses. Am J Ind Med. 1998;33(4):422-4.

32. Kines P, Mikkelsen KL. Effects of firm size on risks and reporting of elevation fall injury in construction trades. J Occup Environ Med. 2003;45(10):1074-8.

33. van Charante AWM, Mulder PG. Reporting of industrial accidents in the Netherlands. Am J Epidemiol. 1998;148:18290.

34. Wickizer TM, Franklin G, Plaeger-Brockway R, Mootz RD. Improving the quality of workers compensation health care delivery: the Washington state occupational health services project. Milbank Q. 2001;79(1):5.

35. Pransky G, Benjamin K, Dembe AE. Performance and quality measurement in occupational health services: current status and agenda for further research. Am J Ind Med. 2001;40(3):295-306.

36. Lim MK. Health and economic impact of occupational health services. SJWEH Suppl 2005;no 1:38-42.

37. Holte HH, Tambs K, Bjerkedal T. Physically demanding situations as predictors of disability pensioning with soft tissue rheumatism among persons 30-39 years old in Norway, 1981-90. J Rheumatol. 2002;29(8):1760-6.

38. Barmby T, Sessions J, Treble J. Absenteeism, efficiency wages and shirking. Scand J Econ. 1994;96(4):561-6.

39. Askildsen JE, Bratberg E, Nilsen OA. Unemployment, labor force composition and sickness absence: a panel data study. Health Econ. 2005;14(11):1087-101.

\author{
J Paul Leigh \\ Center for Health Services Research in Primary Care and \\ Department of Public Health Sciences \\ University of California, \\ Medical School, TB 168 \\ Davis, CA 95616-8638, USA \\ E-mail: pleigh@ucdavis.edu
}

